\title{
PENGARUH KEDALAMAN TANAM TERHADAP PERTUMBUHAN TANAMAN PADI PANDAN PUTRI
}

\author{
Disusun oleh : \\ Angga Adriana Imansyah**) \\ Ahmad Zidni Rodhiya*)
}

\begin{abstract}
Abstrak
Kebutuhan beras yang semakin meningkat mempengaruhi petani untuk melakukan pembaharuan terhadap teknik budidaya yang dilakukan. Teknik budidaya yang baik mengakibatkan tanaman tumbuh dengan baik dan hasil peroduktifitas tinggi, karena teknik budidaya adalah salah satu faktor yang mempengaruhi produktifitas tanaman khususnya pada tanaman padi. Salah satu faktor dalam teknik budidaya yang mempengaruhi pertumbuhan adalah kedalaman penanaman. Penelitian ini dilaksanakan di areal penanaman padi Pandanwangi milik Fakultas Sains Terapan Unsur pada bulan Mei -Juli 2019, menggunaan Rancangan Acak Kelompok yang terdiri dari 6 perlakuan, 3 kelompok dan 3 sampel dalam masing-masing unit percobaan. Enam perlakuan tersebut adalah perlakuan kedalaman tanam $2 \mathrm{~cm}, 4 \mathrm{~cm}, 6 \mathrm{~cm}, 8 \mathrm{~cm}, 10 \mathrm{~cm}$ dan $12 \mathrm{~cm}$. Hasil penelitian menunjukkan hasil yang paling tinggi pengaruhnya terhadap tinggi tanaman adalah perlakuan kedalaman $2 \mathrm{~cm}$ disusul oleh perlakuan kedalaman $4 \mathrm{~cm}$ dan untuk perlakuan kedalaman terhadap panjang akar adalah perlakuan kedalaman $2 \mathrm{~cm}$ dengan rata-rata panjang akar 4, $6 \mathrm{~cm}$.
\end{abstract}

Kata kunci : Padi Pandan Putri, Kedalaman Tanam, Kenaikan Tinggi Tanaman, Panjang Akar.

\begin{abstract}
The increasing need for rice has influenced farmers to renew their cultivation techniques by conducting good cultivation. Techniques resulting in plants growing well and yields high productivity, because cultivation techniques are one of the factors that affect crop productivity, especially in rice plants. One factor in cultivation techniques influence growth is the depth of planting. This research was carried out in the Pandanwangi rice planting area of the Faculty of Applied Elemental Sciences in May-July 2019, using a Randomized Block Design consisting of 6 treatments, 3 groups and 3 samples in each experimental unit. The six treatments are planting depths of $2 \mathrm{~cm}, 4 \mathrm{~cm}, 6 \mathrm{~cm}, 8 \mathrm{~cm}, 10 \mathrm{~cm}$ and $12 \mathrm{~cm}$. The results showed the bighest effect on plant height was the $2 \mathrm{~cm}$ depth treatment followed by the $4 \mathrm{~cm}$ depth treatment and for the root length treatment was $2 \mathrm{~cm}$ depth treatment with an average root length of $4.6 \mathrm{~cm}$.
\end{abstract}

Key words: Pandan Putri Rice, Depth Of Planting, Rise In The High Plants, Long Rots.

*) Alumni Fakultas Sains Terapan UNSUR

**) Dosen Fakultas Sains Terapan UNSUR

\begin{tabular}{|c|c|c|c|}
\hline PENGARUH & KEDALAMAN & TANAM & ANGGA ADRIANA IMANSYAH \\
\hline TERHADAP & PERTUMBUHAN & TANAMAN & AHMAD ZIDNI RODHIYA \\
\hline
\end{tabular}




\section{PENDAHULUAN}

Kebutuhan beras di Indonesia dari tahun ketahun mengalami kenaikan yang mana kebutuhan beras yang meningkat tidak sebanding dengan produksi padi yang dihasilkan, sehingga setiap tahunnya kebutuhan beras tidak terpenuhi (Sari, 2009). Selain daripada itu kandungan energi dalam beras mampu mencukupi 63\% total kecukupan energi dan $37 \%$ protein, sehingga banyak masyarakat indonsia yang menjadikan komoditas padi sangat penting untuk kebutuhan pangan mereka (Norsalis, 2011 dalam Nasution et al., 2013).

Indonesia tercatat sebagai negara dengan konsumsi tanaman padi tertitinggi di dunia. untuk level Asia, Indonesia mengalahkan empat negara yang mengonsumsi tanaman padi tertingi, seperti Korea, Jepang, Malaysia dan Thailand (Ishak et al., 2013). Selain daripada banyaknya konsumen yang mengkonsumsi beras, faktor lain yang mempengaruhi naik turunnya rata-rata produksi padi per hektar adalah masalah kesuburan tanah, curah hujan, kelembapan, pemakaian pupuk, pemilihan bibit, cara bercocok tanam, jasad pengganggu dan sebagainya (Ishak et al., 2013).

Budidaya tanaman padi, dari penyemaian sampai penanama, menurut Ibrahim (2019) teknik penanaman sangat berpengaruh terhadap produksi padi yang ditanam, seperti tingkat kedalaman penanaman bibit padi di lahan penanaman, penanaman bibit yang terlalu dalam akan menghambat pertumbuhan akar dan anakan tanaman yang ditanam.

Pernyataan tersebut sesuai dengan pernyataan dari Yandianto (2003) yang menyatakan Padi atau Oryza sativa termasuk suku rumput-rumputan dan berakar serabut, seperti tanaman rumputrumputan lainnya, padi beranak melalui tunas yang tumbuh dari pangkal batang sehingga membentuk rumpun, jika penanaman semakin dalam maka kemungknan besar pangkal batang yang membentuk tunas akan tertanam dibawah tanah sehingga menghambat pertumbuhan tunas.

Selain dari pada itu kedalaman tanam berhubungan dengan vigor tanaman, bibit normal dari benih yang memiliki kekuatan tumbuh yang baik pada kedalaman optimal namun sebaliknya jika kedalaman kurang optimal benih tidak akan tumbuh dengan baik karena benih memerlukan ruang yang optimal agar dapat berkecambah serta tumbuh (Sadjad, 1997). Sama halnya pada penanaman tanaman jagung yang mana pada kedalaman tanam 2,5-3,5 cm yang memiliki jarak yang hampir sama, pembentukan mesocotyl dan akar adventif dapat terbentuk dengan baik. Sebaliknya pada kedalaman yang terlalu dalam 15-17 $\mathrm{cm}$ dari permukaan tanah, maka coleoptyle akan kering di dalam tanah tanpa membentuk akar adventif yang berakibat bibit akan mati (Santoso dan Purwoko, 2008 dalam Pratama, 2014).

Berdasarkan beberapa hasil penelitian adanya pengaruh kedalaman tanam saat pembibitan pada beberapa tanaman maka kedalaman benih saat tanam sangat penting untuk dipelajari untuk menentukan tingkat kedalaman penanaman yang sesuai agar perkembangan bibit dapat berkembang dengan baik yang ditandai dengan banyaknya anakan dalam satu rumpun tanaman.

\section{METODE PENELITIAN}

Tahapan budidaya tanaman padi Pandan Putri, menurut Ibrahim (2019) tidak berbeda jauh dengan budidaya tanaman yang lainnya. Berikut merupakan tahapan budidaya padi Pandan Putri;

Benih yang digunaan merupakan benih sebar yang hasil seleksi petani. Benih terlebih dahulu disortasi sebelum disemai dengan larutan garam untuk memisahkan benih tidak bernas dan yang hampa. Selama 24 jam benih direndam.

\section{PENGARUH KEDALAMAN TANAM TERHADAP PERTUMBUHAN TANAMAN PADI PANDAN PUTRI} AHMAD ZIDNI RODHIYA 
Bibit dipindah tanamkan sesudah berumur 12 hari.

Setelah 12 hari, bibit dipindahkan ke lahan dengan kedalaman penanaman yang berbeda. Penanaman dibedakan antara kedalaman $2 \mathrm{~cm}, 4 \mathrm{~cm}, 6 \mathrm{~cm}, 8 \mathrm{~cm}$, dan $10 \mathrm{~cm}$. Masing-masing kedalaman berbeda mimiliki sebanyak 5 kali ulangan.

Dalam penelitian ini diguanakan rancangan percobaan acak kelompok dengan tiga kelompok dan 6 perlakuan kedalaman penanaman padi Pandan Putri yang berbeda, sebagaimana berikut;

A : Kedalaman penanaman $2 \mathrm{~cm}$

B : Kedalaman penanaman $4 \mathrm{~cm}$

C : Kedalaman penanaman $6 \mathrm{~cm}$

D : Kedalaman penanaman $8 \mathrm{~cm}$

E : Kedalaman penanaman $10 \mathrm{~cm}$

Dan 3 sampel dalam masing-masing unit percobaan.

Data yang diperoleh diolah menggunakan software Microsof Excell dan SPS, untuk melihat pengaruh dari beberapa jenis perangkap terhadap hama penggerek batang padi yang terperangkap. Selanjutnya dilakukan pengujian Hipotesis dengan uji Duncan Multiple Range Test (DMRT).

\section{HASIL DAN PEMBAHASAN}

Menurut Syukur Makmur Sitompul dan Bambang Guritno (1995) menyatakan bahwa tinggi tanaman merupakan ukuran tanaman yang sering diamati baik sebagai indikator pertumbuhan maupun sebagai parameter yang digunakan untuk mengukur pengaruh lingkungan atau perlakuan yang diterapkan.

Berdasarkan hasil penelitian yang telah dilakukan pengaruh kedalam terhadap tinggi tanaman memiliki pengaruh yang signifikan yang mana kedalaman penanaman dimulai dati $4 \mathrm{~cm}$, $2 \mathrm{~cm}, 6 \mathrm{~cm}, 8 \mathrm{~cm}, 10 \mathrm{~cm}$ dan $12 \mathrm{~cm}$. Data tersebut dihasilakan berdasarkan uji ANOVA (Analisys Of Variance) dengan membandingkan nilai P-Value dengan $\alpha$ 5\% (Lampiran) maka kesimpulannya tolak $\mathrm{H} 0$ dan terima $\mathrm{H1}$ : yaitu artinya terdapat pengaruh kedalaman terhadap tinggi tanaman. Dikarenakan adanya pengaruh maka dilakukan uji lanjut terhadap data tersebut menggunakan uji lanjut DMRT (Duncan Multiple Range Test) yang mana hasilnya ada di dalam table 1.

Tabel 1. Hasil uji DMRT Pengaruh Kedalam Terhadap Kenaikan Tinggi Tanaman yang Dilakukan Selama 15 Hari.

\begin{tabular}{cccccc}
\hline & \multicolumn{5}{c}{ Kenaikan Tinggi Tanaman Padi Pandan Putri (cm) } \\
\cline { 2 - 6 } Kedalaman & \multicolumn{5}{c}{ Waktu Pengamatan (Hari) } \\
\cline { 2 - 6 } & 3 & 6 & 9 & 12 & 15 \\
\hline $\mathrm{A}=2 \mathrm{~cm}$ & $3.9 \mathrm{a}$ & $3.5 \mathrm{a}$ & $5.9 \mathrm{a}$ & $3.4 \mathrm{a}$ & $2.9 \mathrm{a}$ \\
$\mathrm{B}=4 \mathrm{~cm}$ & $3.3 \mathrm{~b}$ & $3.5 \mathrm{a}$ & $4.1 \mathrm{~b}$ & $3.8 \mathrm{a}$ & $3.3 \mathrm{a}$ \\
$\mathrm{C}=6 \mathrm{~cm}$ & $1.6 \mathrm{c}$ & $2 \mathrm{~b}$ & $2.6 \mathrm{c}$ & $2.4 \mathrm{~b}$ & $2.7 \mathrm{a}$ \\
$\mathrm{D}=8 \mathrm{~cm}$ & $0.5 \mathrm{~d}$ & $1.5 \mathrm{~b}$ & $1.6 \mathrm{c}$ & $1.5 \mathrm{c}$ & $1.3 \mathrm{~b}$ \\
$\mathrm{E}=10 \mathrm{~cm}$ & $0.2 \mathrm{~d}$ & $0.3 \mathrm{~d}$ & $0.3 \mathrm{~d}$ & $0.3 \mathrm{~d}$ & $0.2 \mathrm{bc}$ \\
$\mathrm{F}=12 \mathrm{~cm}$ & $0.0 \mathrm{~d}$ & $0.0 \mathrm{~d}$ & $0.0 \mathrm{~d}$ & $0.0 \mathrm{~d}$ & $0.0 \mathrm{c}$
\end{tabular}

Keterangan: Angka yang diikuti huruf yang sama menunjukan tidak ada beda nyata bedasakan uji DMRT.

Hasil penelitian pada pengamatan hari ketiga menunjukkan perlakuan A (kedalaman $2 \mathrm{~cm}$ ) berdasarkan tabel 4.1 merupakan nilai rata-rata tinggi tanaman yang paling besar dibandingkan kelima perlakuan lainnya. Perlakuan A (kedalaman 2cm), B (kedalaman $4 \mathrm{~cm}$ ), dan C (kedalaman $6 \mathrm{~cm}$ ) menunjukan hasil

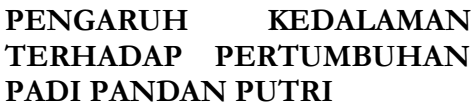


yang berbedanyata dengan perlakuan lainnya. Sedangkan perlakuan D (kedalaman $8 \mathrm{~cm}$ ), E (kedalaman $10 \mathrm{~cm}$ ), dan F (kedalaman $12 \mathrm{~cm}$ ) menunjukkan hasil yang tidak berbeda nyata.

Pada waktu pengamatan hari keenam perlakuan A (kedalaman $2 \mathrm{~cm}$ ) dan B (kedalaman 4cm) menunjukkan hasil rata-rata tinggi tanaman yang sama dan tidak berbeda nyata yaitu sebesar $3.5 \mathrm{~cm}$. Akan tetapi kedua perlakuan ini menunjukkan hasil yang berbeda nyata dengan keempat perlakuan lainnya. Perlakuan C (kedalaman 6cm) dan D (kedalaman $8 \mathrm{~cm}$ ) menunjukan hasil yang tidak berbeda nyata begitu pula untuk perlakuan E (kedalaman $10 \mathrm{~cm}$ ) dan $\mathrm{F}$ (kedalaman $12 \mathrm{~cm}$ ) menunjukkan hasil yang tidak berbeda nyata.

Untuk pengamatan hari kesembilan menunjukkan perlakuan $\mathrm{B}$ (kedalaman $4 \mathrm{~cm}$ ) berdasarkan tabel 4.1 merupakan nilai rata-rata tinggi tanaman yang paling besar dibandingkan kelima perlakuan lainnya. Perlakuan A (kedalaman $2 \mathrm{~cm}$ ) dan B (kedalaman $4 \mathrm{~cm}$ ) menunjukan hasil yang berbedanyata, sedangkan perlakuan $\mathrm{C}$ (kedalaman $6 \mathrm{~cm}$ ) dan D (kedalaman $8 \mathrm{~cm})$ serta $E$ (kedalaman $10 \mathrm{~cm}$ ) dan F (kedalaman $12 \mathrm{~cm})$ menunjukkan hasil yang tidak berbeda nyata.

Pengamatan pada hari kedua belas perlakuan A (kedalaman $2 \mathrm{~cm}$ ) dan B (kedalaman $4 \mathrm{~cm}$ ) menunjukkan hasil yang tidak berbeda nyata dan merupakan nilai rata-rata tinggi tanaman yang paling besar. Hasil penelitian juga muenunjukkan perlakuan C (kedalaman $6 \mathrm{~cm}$ ) dan D (kedalaman $8 \mathrm{~cm}$ ) berbeda nyata sedangkan perlakuan E (kedalaman $10 \mathrm{~cm}$ ) dan F (kedalaman $12 \mathrm{~cm}$ ) menunjukkan hasil yang tidak berbeda nyata.

$$
\text { Pada pengamatan hari }
$$

kelimabelas perlakuan B (kedalaman $4 \mathrm{~cm}$ ) masil menunjukan nilai rata-rata tinggi tanaman paling besar, akan tetapi hasil tersebut tidak berbeda nyata dengan perlakuan A (kedalaman 2cm) dan C (kedalaman $6 \mathrm{~cm}$ ). Perlakuan D (kedalaman $8 \mathrm{~cm}$ ) tidak berbeda nyata dengan perlakuan E (kedalaman $10 \mathrm{~cm}$ ) tetapi berbeda nyata dengan pelakuan $\mathrm{F}$ (kedalaman $12 \mathrm{~cm}$ ). Dan perlakuan $\mathrm{E}$ (kedalaman $10 \mathrm{~cm}$ ) tidak berbedanyata dengan perlakuan F (kedalaman 12cm).

Berdasarkan hasil penelitian kedalaman tanam yang baik untuk pertumbuhan tinggi tanaman padi pandan putri yang berkisar antara 2,7-3,3 cm ditunjukan oleh perlakuan $\mathrm{A}(2 \mathrm{~cm})$, kedalaman $\mathrm{B}(4 \mathrm{~cm})$, dan $\mathrm{C}(6 \mathrm{~cm})$ dengan hasil analissi statistic yang tidak berbedanyata, hal ini sesuai dengan pernyataan Idawani (1994) bawa penanaman bibit padi pada umumnya tidak boleh kurang dari $2 \mathrm{~cm}$. karena jika kursng dsri $2 \mathrm{~cm}$, tanaman akan mudah hanyut. Begitupula menurut Hendrata dalam Fitriani et al., (2017) tingkat kedalaman tanam tanaman padi dapat diatur dengan ukuran 0,7-3,7 cm.

Pengaruh kedalaman tanam terhadap tinggi tanaman padi Pandan Putri terdapat pada perlakuan A (kedalaman $2 \mathrm{~cm}$ ) dan B (kedalaman $4 \mathrm{~cm}$ ) yang mana hal ini sesuai dengan pernyataan Kementan (2014) bahwa kedalaman tanam 2-4cm merupakan ukuran yang ideal untuk metode penanaman SRI.

Selain dari pada itu pada kedalaman tanam mempengaruhi cekaman yang terjadi dari tiap bibit tanaman untuk tumbuh secara optimal dan juga bibit yang dipilih merupan bibit yang memiliki akar muda (Anonymous, 2009).

Tidak hanya itu kedalam tanam akar tanaman tertekan yang membuat terhambatnya penyerah air dan nutrisi sehingga pertumbuhan menjadi lambat. Proses respirasi pada akar juga terhambat karena semakin dalam lapisan tanah kandungan oksigen semakin sedikit (Beukema, 1990)

\section{PENGARUH KEDALAMAN TANAM TERHADAP PERTUMBUHAN TANAMAN PADI PANDAN PUTRI}




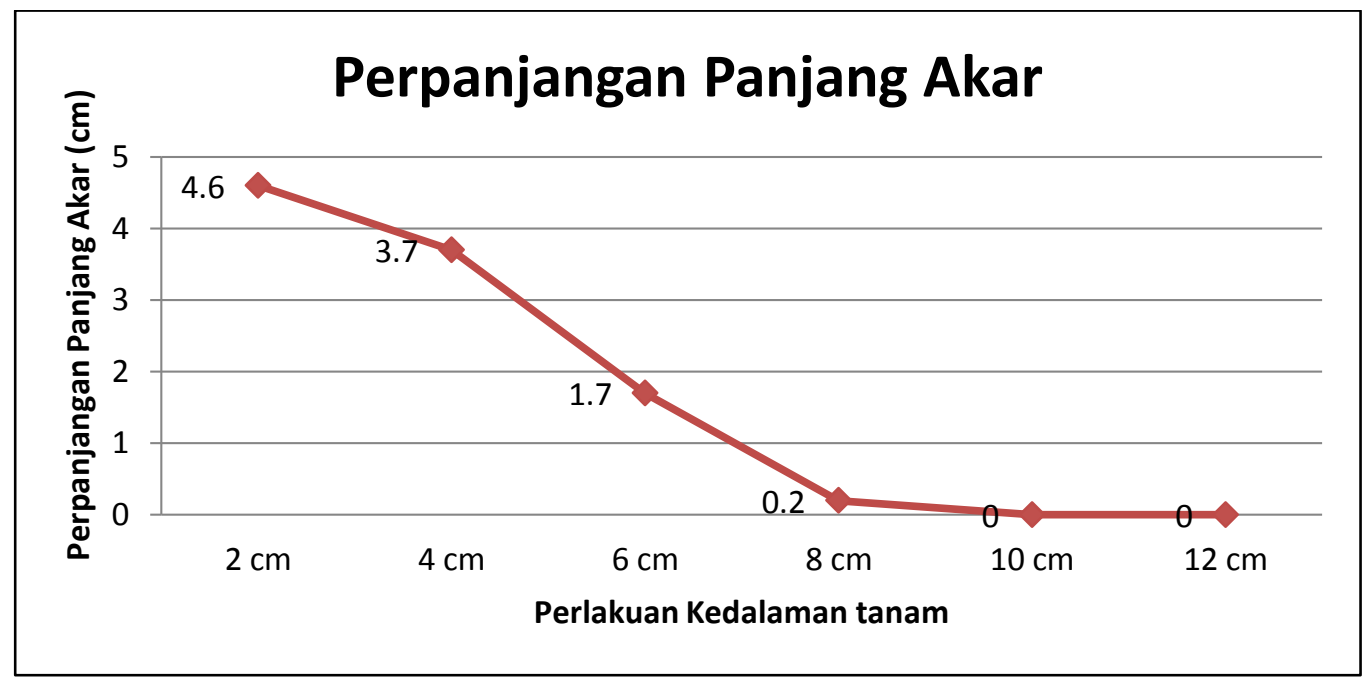

Garfik 1. Pengaruh Kedalaman Tanam Terhadap Panjang Akar Tanaman Padi.

Pada pengamatan selama 15 hari ke empat perlakuan kedalaman berpengaruh terhadap panjang akar perlakuan A (kedalaman 2cm) menunjukan hasil yang lebih tinggi dibandingkan dengan kedalaman tanam lainnya, pada pengamatan pertama perlakuan A (kedalaman 2cm) berbeda nyata dengan dengan perlakuan semua kedalaman, begitu pula dengan perlakuan B (kedalam 4cm) dan C (kedalaman $6 \mathrm{~cm}$ ) memiliki pengaruh yang berbeda nyata dengan perlakuan lainnya, akan tetapi untuk perlakuan D (kedalaman $8 \mathrm{~cm}$ ), E (kedalaman $10 \mathrm{~cm}$ ) dan F (kedalaman $12 \mathrm{~cm})$ tidak berbeda nyata namun berbeda nyata dengan perlakuan A (kedalaman $2 \mathrm{~cm}$ ), B (kedalaman $4 \mathrm{~cm}$ ) dan C (kedalaman $6 \mathrm{~cm}$ ).

Perkembangan sistem perakaran dipengaruhi oleh faktor lingkungan. Faktor lingkungan yang mempengaruhi sistem perakaran di dalam tanah adalah kelembaban tanah, suhu tanah, keasaman tanah, aerasi tanah, hambatan mekanis tanah, kompetisi dan interaksi perakaran (Ismail dan Utomo (1995).

Berkaitan dengan pengaruh kedalaman terhadap panjang akar yang mana pada hasil penelitian menunjukan semakin dangkal penanaman maka semakin panjang akarnya ada beberapa faktor yang mempengaruhinya selain daripada faktor tanah yaitu faktor dari ketersediaan air yang mana pada saat penanaman ketersediaan air dipermukaan terpenuhi sehingga ditanam secara dangkal pun itu baik untuk pertumbuhan akar karena akar akan menjalar mencari nutrisi dan air ke sekitarnya tanpa harus menembus bagian tanah paling dalam seperti contoh kasus pada saat kekeringan, selain daripada itu ketika akar tembus ke bagian bawah permukaan tanah akan berpengaruh terhadap respirasi akar yang mana pada bagian tanah yang paling dalam itu ketersediaan oksigen semakin sedikit maka hal tersebut pun akan berpengaruh terhadap pertumbuhan tanaman padi (Kamil, 1998 dalam Fatchullah, 2016).

\section{KESIMPULAN}

Kedalaman tanam yang berbeda pada padi Pandan Putri berpengaruh terhadap tinggi tanaman dan panjang akar yang mana kedalaman tanam yang paling berpengaruh adalah perlakuan A (kedalam $2 \mathrm{~cm})$ dan diteruskan oleh perlakuan B (kedalaman 4cm), sedangkan untuk perlakuan C (kedalaman $6 \mathrm{~cm}), \mathrm{D}$ (kedalaman $8 \mathrm{~cm}), \mathrm{E}$ (kedalaman $10 \mathrm{~cm}$ ),

\section{PENGARUH KEDALAMAN TANAM TERHADAP PERTUMBUHAN TANAMAN PADI PANDAN PUTRI}


dan F (kedalaman 12cm) kurang tepat untuk pertumbuhan tinggi tanaman padi.

\section{DAFTAR PUSTAKA}

Ai, S, N dan Torey, P. 2013. Karakter Morfologi Akar sebagai Indikator Kekurangan Air pada Tanaman. Jurnal Bioslogos 3(1):31-39. Universitas Sam Ratulangi Manado.

Aak. 1995. Budidaya Tanaman Padi. Kanisius: Jakarta.

Anonymous. 1990. Budidaya Tanaman Padi. Kanisius. Jakarta.

Ashari, S. 2006. Hortikultura Aspek Budidaya. UI press. Jakarta. 490 pp.

Beukema, H,P dan D,E Van Der Zaag. 1990. Introduction to Potato Productian. PUDOC. Wageningen.

Fatchullah, D. 2016. Pengaruh Jarak Tanam dan Kedalaman terhadap Pertumbuhan dan Hasil Tanam Kentang (Solanum tuberosum L) Generasi 2 Varietas Granola. Prosiding Seminar Nasional : 95-105. Balai Penlitian Tanaman Sayuran. Lembang.

Firiani, R., Tyasmoro, Y, S dan Suryanto, A. 2017. Pengaturan Jarak Tanam dan Jumlah Bibit Perlubang pada Mesin Tanam Rice Transparanter Terhadap Padi Sawah (Oryza sativa L)Varietas Ciherang. Jurnal Produksi Tanaman 5(6):1015-1022.

Ibrahim. 2019. Teknik Budidaya Tanaman Padi Pandan Putri. Komunikasi Pribadi. Warungkondang, Cianjur.

Idawanni. 1994. Persiapan Bibit dan Cara Tanam Padi Sawah. Badan Peneliti dan Pengembangan Pertanian.

Ishak,Y.S., Bahua,I.M., dan Limonu,M. 2013. Pengaruh Pemberian Pupuk Urea dan Pupuk Kandang Ayam terhadap Pertumbuhan dan Hasil Tanaman Jagung Manis. Jurnal Variabel Pertanian. 10 (1): 119
Ismail, T dan Utomo, W, H.1995. Hubungan Tanah Air dan Tanaman. IKIP Semarang Press. Semarang. Hal 297.

Kamil, J. 1986. Teknologi Benih. Rajawali. Jakarta.

Marzukoh, U,R., Sakya, T, A dan Rahayu, M. 2013. Pengaruh Volume Pemberian Air terhadap Pertumbuhan Tiga Varietas Tomat (Lycopersicum esculentum Mill). Jurnal Agrosains 15(1): 12-16.

MP3C. 2015. Permohonan Pendaftaran Indikasi Geografis Beras Pandanwangi. Cianjur.

Nasution, H,F., Ginting, J dan Siagian. B. 2013. Tanggap Pertumbuhan dan Produksi Padi Gogo Varietas Situ Bagendit Terhadap Pengolahan Tanah dan Frekuensi Penyiangan yang Berbeda. Jurnal Online Agroekoteknologi. 1(2): 2337-6597. Fakultas Pertanian USU Medan.

Nofyangtri S (2011). Pengaruh Cekaman Kekeringan dan Aplikasi Mikoriza terhadap MorfoFisiologis dan Kualitas Bahan Organik Rumput dan Legum Pakan. Tesis. Institut Pertanian Bogor.

Pratama,W,H., Baskara, M dan Guritno, B. 2014. Pengaruh Ukuran Biji dan Kedalaman Tanam Terhadap Pertumbuhan Dan Hasil Tanaman Jagung Manis (Zea mays saccharata Sturt). Jurnal Produksi Tanaman. 2(7):576-582. Fakultas Pertanian. Universitas Brawijaya. Malang.

Panudji, I, T. 2014. Pedoman Teknis Pengembangan SRI TA. Direktorat Perluasan dan Pengelolaan Lahan.

Rembang, W., H., J., Rauf, W., A dan Sondakh, M.,O.,J. 2018. Karakter Morfologi Padi Sawah Lokal di Lahan Petani Sulawesi Utara. Buletin Plasma Nutfah.24(1) : 1-8.

\section{PENGARUH


Rosadi, N., F. 2013. Studi Morfologi dan Fisiologi Galur Padi (Oryza sativa L.) Toleran Kekeringan. Tesis. Sekolah Pascasarjana Institut Pertanian Bogor Bogor.

Sadjad, S. 1997. Membangun Indrusti Benih datam Era Agribisnis Indonesia. Garsindo. Jakarta.

Samanhudi. 2010. Pengujian Cepat Ketahanan Tanaman Sorgum Manis Terhadap Cekaman Kekeringan. Jurnal Agrosains 12(1): 9-13.

Santoso, B dan Purwoko, S, B. 2008. Pertumbuhan Bibit Tanaman Jarak Pagar (Jatropha curcas L.) pada Berbagai Kedalaman dan Posisi Tanam Benih. Jurnal Bul. Agron 36 (1):70 - 77.

Sari, N, E. 2009. Pertumbuhan dan Produksi Padi yang Ditanam dengan Metode System Of Rice Intensification (S.R.I.) Di Desa Limo, Depok, Jawa Barat. Skripsi. Program Studi Manajemen Sumberdaya Lahan. Fakultas Pertanian IPB.

Sari, N, D., Sumardi dan Suprijono, E. 2014. Pengujian Berbagai Tipe Tanam Jajar Legowo terhadap Hasil Padi Sawah. Jurnal Akta Agrosia. 17 (2): 115 - 124. Program Studi Agroekoteknologi. Fakultas Pertanian. Universitas Bengkulu.

Siregar, H. 1981. Budiddaya Tanaman Padi di Indonesia. Sastra Hudaya: Bogor.

Sitompul,S.M. dan B. Guritno. 1995. Analisis Pertumbuhan Tanaman. Gadjah Mada University Press. Yogyakarta, hal. 24.
Wibowo, P. 2010. Pertumbuhan dan Produktivitas Galur Harapan Padi (Oryza Sativa L.) Hibrida di Desa Ketaon Kecamatan Banyudono Boyolali. Skripsi. Fakultas Pertanian Universitas Sebelas Maret Surakarta.

Yandianto. 2003. Bercocok Tanam Padi. Percetakan M2S. Bandung.

\section{PENGARUH KEDALAMAN TANAM

ANGGA ADRIANA IMANSYAH AHMAD ZIDNI RODHIYA 